Emotions and Loneliness in a Networked Society

Edited by

Bianca Fox 


\section{Bianca Fox}

Editor

\section{Emotions \\ and Loneliness \\ in a Networked \\ Society}

palgrave macmillan 
Editor

Bianca Fox

University of Wolverhampton

Wolverhampton, UK

ISBN 978-3-030-24881-9

ISBN 978-3-030-24882-6 (eBook)

https://doi.org/10.1007/978-3-030-24882-6

(C) The Editor(s) (if applicable) and The Author(s), under exclusive license to Springer

Nature Switzerland AG 2019

This work is subject to copyright. All rights are solely and exclusively licensed by the Publisher, whether the whole or part of the material is concerned, specifically the rights of translation, reprinting, reuse of illustrations, recitation, broadcasting, reproduction on microfilms or in any other physical way, and transmission or information storage and retrieval, electronic adaptation, computer software, or by similar or dissimilar methodology now known or hereafter developed.

The use of general descriptive names, registered names, trademarks, service marks, etc. in this publication does not imply, even in the absence of a specific statement, that such names are exempt from the relevant protective laws and regulations and therefore free for general use. The publisher, the authors and the editors are safe to assume that the advice and information in this book are believed to be true and accurate at the date of publication. Neither the publisher nor the authors or the editors give a warranty, expressed or implied, with respect to the material contained herein or for any errors or omissions that may have been made. The publisher remains neutral with regard to jurisdictional claims in published maps and institutional affiliations.

Cover image: (C) Alex Linch/shutterstock.com

Cover design by eStudioCalamar

This Palgrave Macmillan imprint is published by the registered company Springer Nature Switzerland AG

The registered company address is: Gewerbestrasse 11, 6330 Cham, Switzerland 


\title{
Making Sense of The Lonely Crowd, Today: Youth, Emotions and Loneliness in a Networked Society
}

\author{
Rosalina Pisco Costa, Paulo Infante, Anabela Afonso \\ and Gonçalo Jacinto
}

\section{INTRODUCTION}

The Lonely Crowd: A Study of the Changing American Character (Riesman et al. 1950) was a landmark in the twentieth mid-century social science and cultural criticism (McLaughlin 2001). While it led the yet almost unknown sociologist David Riesman (1909-2002) to the cover of Time magazine in $1954,{ }^{1}$ the book asserted itself as a critical and attentive look at a changing society. Increasingly away from a society based on production and

R. P. Costa $(\bowtie)$

Universidade de Évora, Department of Sociology

and CICS.NOVA.UÉvora-Interdisciplinary Centre

of Social Sciences, Évora, Portugal

e-mail: rosalina@uevora.pt

P. Infante $\cdot$ A. Afonso $\cdot$ G. Jacinto

Universidade de Évora, Department of Mathematics and CIMA-Research

Center in Mathematics and Applications, Évora, Portugal

(C) The Author(s) 2019

B. Fox (ed.), Emotions and Loneliness in a Networked Society, https://doi.org/10.1007/978-3-030-24882-6_8 
characterized by a "tradition-directed" culture, Riesman's Lonely Crowd unveiled the individuals' character composing that new society, fundamentally shaped by the market orientation of a consumer and media culture, and thus "other-directed".

In the period of post-World War II, a context of strong industrialization and automation, Riesman explained how and why the other-directed character was beginning to flourish among middle-class individuals. This chapter attempts to make use of such a broad and inspiring theoretical background to unveil the senses of the lonely crowd, today, specifically as far as the youngest generation is concerned. Particularly looking at iGen, Generation $\mathrm{Z}$ or centennials, as often referred to (Twenge 2017), the following discussion takes as its basic assumption the existence of a networked society as a constitutive feature of such a generation, yet only seemingly irrelevant in the everyday experiences of individuals.

Empirically, data were collected from a representative sample of young people, studying in secondary schools in Évora, a city in the south of Portugal (Europe). Through a face-to-face questionnaire, students answered several questions about their everyday life, satisfaction with the present times and ideas about the future. Particularly, students were asked about their sociocultural practices, such as things they enjoy doing in free time, uses of social media and networks and its frequency, and civic intervention practices, such as belonging to any association, organization or club and corresponding forms of participation. This chapter makes use of statistical analysis to unveil relations between social media participation and experiences of being accompanied and being alone with civic intervention practices and satisfaction with life. Sociologically anchored, the paper ultimately discusses if, and how, today's society is impelling young individuals to experience loneliness, thus exploring different senses of the lonely crowd in a networked and "other-directed" society.

The inspiring and insightful work of Riesman is explored hereafter in understanding contemporary youth. Ideas imported from The Lonely Crowd are used to question data and to organize the results' section. Before that, the methodology is detailed, specifically as far as the background and research design, sample and data analysis procedures are concerned. By the end, the concluding remarks synthesize the meanings found for the senses of the lonely crowd, today, while expanding the discussion for those joining, avoiding or engaging the crowd. Although data draw from a reality geographically located in southern Europe, it is expected this paper might 
contribute to advance understanding on the contemporary and globalized relations between emotions and loneliness, as Riesman wisely put it.

\section{The Lonely Crowd in the 5os. How Did We Get THERE?}

Although not exempt from critics, controversy and academic oblivion (Heberle 1956; Lipset and Lowenthal 1961; Gans et al. 1979; McLaughlin 2001; Barthel-Bouchier 2019), Riesman's The Lonely Crowd (1950) may well be the best-selling sociology book of all time (Gans 1997). ${ }^{2}$

In The Lonely Crowd, Riesman, Glazer and Denny pointed out a major change over time in the American character, distinguishing between societies tradition-directed, inner-directed and other-directed. Riesman and his co-authors underline that changes are always contextual, those, in particular, being strongly intertwined with history, mobility and technology, changing demographics ${ }^{3}$ and the emergence of a service and consumptionbased economy. Specific characters ensure conformity in different historical periods and types of societies, and according to the authors, the same was happening within American society of that time. Moreover, the authors argue that the predominant character in a specific time affects every aspect of American life, namely the relation individuals establish, both in the more public social arenas, such as work and labor, family, religion, economy and business, leisure or politics, and also at the private level of the intimate relationships and emotions, including both practices and symbolic meanings. Without going too deeply into the considerations presented in The Lonely Crowd, neither in its theoretical roots nor influential power onward, and although those are more ideal types, in the Weberian form, sometimes in a predominant way, other combined, it is worth distinguishing between those three concepts in the view of this chapter development.

Tradition-directed societies, of which the Middle Ages can be considered an iconic period, were characterized by “... their relative slowness of change, their dependence on family and kin organization, and-in comparison with later epochs - their tight web of values" (Riesman et al. 1989 [1950], p. 13). Accordingly, therein the activity of the individual is determined strongly by the past, namely by "characterologically grounded obedience to traditions" (Riesman et al. 1989 [1950], p. 11), which can be fixed by a particular age-grade, clan or caste, learned by the young throughout socialization and modified, yet slightly, as the generations succeed each other. This way, intensive socialization, routine and rituals provide the script 
for rigid etiquette as far as values and behaviors are concerned. In the same way, as the tradition-directed type was the product of unchanging societies, so the traditional character was rigid, stable and unresponsive to innovation. The guiding emotion for this type is shame, made visible through coercion and communal pressures ensuring conformity in traditional societies.

As for the type of character designated as inner-directed, in western history, it can be found in the kind of society that emerged with the Renaissance and Reformation, and then consolidated in the nineteenth-century with industrialization and the rise of the "self-made" man. Therein, innerdirection is the main mode of securing conformity. It is a society "characterized by increased personal mobility, by a rapid accumulation of capital (teamed with devastating technological shifts), and by an almost constant expansion: intensive expansion in the production of goods and people, and extensive expansion in exploration, colonization, and imperialism" (Riesman et al. 1989 [1950], p. 14). In this society, "the source of direction for the individual is 'inner' in the sense that it is implanted early in life by the elders and directed toward generalized but nonetheless inescapably destined goals" (Riesman et al. 1989 [1950], p. 15). In a context of rapid economic expansion, services and technological transition, where novel problems and opportunities arise in every moment, the inner-directed figure is self-motivated. Having received its essential structure of lifelong goals and values during youth, through socialization, this character could change more easily than the traditional type, yet only following the direction of his or her internalized "gyroscope", 4 which essential pattern had been previously determined in youth. The guiding emotion for this type of character is guilt, felt whenever the individual cannot keep in line with social expectations.

Lastly, the type of character described as other-directed was defined by Riesman and his collaborators as emerging in the beginning of the twentieth century in the "new" and young upper-middle class, in close relation with the capitalism, industrialism and urbanization. Metropolitan America in the mid-twentieth century serves as an illustration of a type of society wherein other direction is the dominant mode of insuring conformity. The turning point had to do with the way education, leisure and services' development went together with an increased consumption of messages; values and ideals spread through the new mass media of communications, including movies, radio, comics and popular culture media generally. In short, "what is common to all the other-directed people is that their contemporaries are the source of direction for the individual — either those known to 
him or those with whom he is indirectly acquainted, through friends and through the mass media" (Riesman et al. 1989 [1950], p. 21). As a consequence, the other-directed character relies less at tradition and their elders, and heavily on peer relationships (schoolfellows, coworkers and contemporaries), and mass media, as individuals are often behaving according to what other people expect of them and, thus, more attentive to that permanent judgment or approval of his or her own standards of behavior. Differently from a gyroscope, the other-directed individuals use a "radar", through which they are sensitive to the desires of others, and constantly receiving information from them-therefore, flexibly guiding their values and action. As a consequence, the guiding emotion for this type is anxiety, precisely because individuals inescapably face the pressure of being liked and positively evaluated according to messages coming from their peers. The other-directed individual needs to be loved (more than esteemed) and to receive the signals of it. As Riesman claims, "while all people want and need to be liked by some of the people some of the time, it is only the modern other-directed types who make this their chief source of direction and chief area of sensitivity" (Riesman et al. 1989 [1950], p. 22).

The book attempts to capture such a scenario through its paradoxical title. The Lonely Crowd is the image of a set of individuals only apparently together, as in nowadays' society individual members feel themselves alone, depending on others when looking for a meaning in their lives. The crowd that Riesman refers to is labeled as "lonely" because the otherdirected character challenges personal rootedness, identity and sense of place. According to the authors, "The other-directed person is cosmopolitan. For him the border between the familiar and the strange-a border clearly marked in the societies depending on tradition-direction - has broken down. As the family continuously absorbs the strange and reshapes itself, so the strange becomes familiar. While the inner-directed person could be 'at home abroad' by virtue of his relative insensitivity to others, the other-directed person is, in a sense, at home everywhere and nowhere, capable of a rapid if sometimes superficial intimacy with and response to everyone" (Riesman et al. 1989 [1950], p. 25).

The face of Riesman in the cover of Time and the 1,000,000 million copies sold by 1971 constitute objective and impressive indicators that Riesman's The Lonely Crowd did not go unnoticed to the contemporary society of his time. Within sociologists, there are different views regarding both the value and impact of this work. ${ }^{5}$ The Lonely Crowd is often accused of being an easy, commercial and generalist writing while doubts arise 
about the methodology used and the validity of the conclusions obtained (Heberle 1956; Lipset and Lowenthal 1961). On the contrary, Riesman can be seen as a valuable, influential and even though forgotten sociologist of the twentieth-century American sociology, who played a significant role as an intellectual, being able to speak to a broader audience and to anticipate with clarity important social shifts (Wrong 1992; McClay 1998).

Dennis Wrong finishes a revisit over The Lonely Crowd in the Sociological Forum, saying that the scientific community was starting to look at some recent cultural changes with some distance and outwardness. He claims, "We are getting, however, back on track, and Riesman saw the track 40 years ago" (Wrong 1992, p. 389). Accordingly to this thought, in a paper published in 2001 in The American Sociologist, Neil McLaughlin affirmed that "Riesman's relatively neglected theoretical approach has much to offer a sociology concerned with retaining its links to public debate and empirical evidence" (McLaughlin 2001, p. 5), and added that he "has never received the recognition he deserves in American sociology" (McLaughlin 2001, p. 19). Will this be the time? To what extent The Lonely Crowd can be a reading frame to understand the current generation? What is (still) the place of Riesman's work in understanding contemporary society, and youth in particular?

\section{The Online Crowd ${ }^{6}$ : What Is Happening Today?}

Neil McLaughlin argues that "there is much of Riesman's analysis that rings true today" (McLaughlin 2001, p. 15). Undoubtedly, the idea of a "lonely crowd" is easily expanded into the "online crowd" (Stage 2013). With the rise of the Internet, the generalization of using mobile devices to allow instant communication and, more recently, the pervasive use of social media, the ideas presented in Riesman's book seem as current as in the 50s. Around the world, today's young generation experiences as never the power of the crowd, as easily perceived through their networked lives (Boyd 2014; Livingstone and Haddon 2009). Beyond their peers, physically near, they face the constant and immediate presence of others in the networked society: family and friends, but also pseudo-friends, unknown characters and even celebrities with whom they establish a virtual, yet at same point, real relation through social media and software applications, such as Facebook and Instagram accounts, WhatsApp groups or YouTube videos. 
Especially the iGen, this is, individuals born in the beginning of the twenty-first century, they are not just receiving influence from the mass media; they are media themselves (Twenge 2017), as they are communicating, sharing information, acting and feeling with others across the country (and globe) at any minute. As a consequence, the metaphor of the "radar", used by Riesman and his co-authors, is even more complex as "signals" constantly increase both in number and impact. Moreover, those signals have a visible and comparable dimension, quantified in the number of views, likes, comments, shares, followers, post reach or page engagements.

Beyond its paradoxical title, The Lonely Crowd presented a nuanced perspective over the other-directed society which echoes today. As recognized in the 1961 preface, the other-directed character has positive aspects yet underemphasized. Riesman particularly refers to “... the considerateness, sensitivity, and tolerance that are among the positive qualities of otherdirection" (Riesman et al. 1989 [1950], p. xxxii). He continues detailing the benefits and advantages of the other-directedness: "There has been a general tendency, facilitated by education, by mobility, by the mass media, toward an enlargement of the circles of empathy beyond one's clan, beyond even one's class, sometimes beyond one's country as well. That is, there is not only a great psychological awareness of one's peers but a willingness to admit to the status of peer a wider range of people, whether in one's own immediate circle or vicariously through the mass media" (Riesman et al. 1989 [1950], p. xxxiii).

Recent studies found that being online increases the sense of community, support and trust while other studies come to question this positive power, drawing particular attention on the risk agenda around youth and social media (Haddon 2015). The warning comes from studies relating the use of the Internet and social media as a source of pressure, anxiety, distress and unhappiness (Mascheroni and Olafsson 2014; Thompson et al. 2018). In short, this means that being part of the online crowd, this is, sharing information, photos or comments, can be as positive as negative or as pleasurable as painful.

Recent years have witnessed increasing concerns surrounding the consequences of the widespread diffusion of Internet-enabled mobile devices such as smartphones for well-being in general, family and personal time, and health in particular. For instance, a very recent study examining the impact of digital mobile devices on different aspects of family time in the UK has found that while children are spending more time at home with 
their parents, that time isn't being occupied with sharing more activities together, such as watching TV and eating. The increase is in what is called "alone-together" time (Mullan and Chatzitheochari 2019).

Consistently with that, a study developed with Portuguese adolescents and young adults has indicated that while social networking was reported as among the main preferences by both females and males when being on the Internet, online communication likely engenders feelings of loneliness (Costa et al. 2018). At the same time, it raises the discussion about the implications and effectiveness of digital parenting to deal with the many challenges that contemporary youth faces (Mascheroni et al. 2018). The issue seems to be non-exclusively related to Internet addiction or problematic Internet use, and it comes to question the relation between others' acceptance, loneliness, happiness and self-esteem, as Riesman before and more recently put it (Riesman et al. 1989 [1950]; Riesman 1998).

Having these questions as a background, it is worth asking: What is the relation between participating in the online crowd and broad satisfaction in life? Specifically, what are the activities that young people enjoy doing in their free time? Do those include networking or being alone, and how much time do they allocate to it? Moreover, what are the relations between the degrees of satisfaction among students who refer that in their free time prefer being with friends, to participate in social networks/spaces or being alone? Lastly, what are the factors that significantly increase the probability of a student spending a great amount of time on social networks?

\section{Methods \\ Background and Research Design}

This chapter draws on data collected from a major study carried out in the framework of the Youth Plan for the Municipality of Évora (Infante et al. 2018). Évora is a city with a little more than 50,000 inhabitants located in the south of Portugal, Europe.

The Municipality of Évora is committed to elaborate the first Youth Plan. Such a document ultimately seeks to answer to the various challenges youth faces and, at the same time, to plan the development and implementation of innovative and cross-cutting youth policies, establishing resources and services allowing young people to achieve full citizenship.?

The first step in the construction of the Youth Plan was to make an accurate and up-to-date characterization of the youth of Évora, namely of 
those who study, work or live in the Municipality of Évora, aged between 15 and 29 years.

This paper focuses only on students from Évora secondary schools in the academic year $2017 / 2018$, as this particular study was based on a representative sample.

A cross-sectional quantitative study was developed, and data were collected through a face-to-face questionnaire, in a paper format, selfadministered by students.

Broadly, the research was designed in order to answer the following questions: Who are the young people from Évora? How do they live present times? What future do they yearn for? Specifically, the questionnaire was divided into six sections, each including questions aiming to collect detailed information having the following objectives in mind: (i) to outline the socio-demographic profile of young people in the Municipality of Évora; (ii) to describe the modes of school participation; (iii) to characterize sociocultural practices; (iv) to characterize the practices of civic intervention; (v) to identify risk behaviors; (vi) to know the level of satisfaction with life and ideas of the future.

\section{Sample}

The target population was defined as the total of secondary school students in the county of Évora, in the academic year 2017/2018.

A sample of 33 classes, which corresponded to 761 young people from the secondary schools' population, was drawn by a multistage stratified random sampling method. The sample size was obtained from a random sample formula, for a sample error below 3.5\%, at a confidence level of $95 \%$, for estimations of $30 \%$ corrected by a design effect of 1.5 .

At a first stage, each of the four secondary schools was stratified by year level. At a second stage, classes were selected in each school and year level using a simple random sampling design without replacement. Selection of the classes was proportional to the number of classes by year and school. Data were collected during October and November of 2017. Participation of individuals in the study was voluntary and anonymous. All students in the selected classes who had their informed consent declarations duly signed by their parents were included in the study.

Authorization for accessing the school classrooms was previously obtained from the government responsible for education (Direção Geral da Educação e Agrupamentos), after consulting the National Commission for 
Data Protection (Comissão Nacional de Proteção de Dados). Participants were formerly informed about the objectives of the survey. Oral consent was obtained from them, and written consent from their parents, what happened in all cases students were under 18 years old.

The data collected at the various schools were gathered by the research team, processed by computer and submitted to a preliminary treatment for quality analysis. Overall, the questionnaire had a high level of adherence by the respondents, as the majority of questions had a response rate higher than $98 \%$.

The total sample size included in the presented study consists of 674 students-314 males and 357 females, aged between 15 and 24 years (mean $=16.9, \mathrm{SD}=1.5$ ), which corresponds to $30.7 \%$ of the target population (Table 8.1). Most of the students live with their parents and siblings in

Table 8.1 Summary statistics for gender, household members and academic qualifications of the parents

\begin{tabular}{llr}
\hline Variable & Category & $\%$ \\
\hline Gender & Female & 53.2 \\
Number of household members & Male & 46.8 \\
& 1 & 1.8 \\
& 2 & 10.0 \\
& 4 & 31.4 \\
With whom lives the student & 5 and more & 41.6 \\
(composition of household in addition & Father/stepfather and & 15.2 \\
to his own) & mother/stepmother and siblings & 51.8 \\
& Father/stepfather and & 18.1 \\
& mother/stepmother & 11.2 \\
& A parent and siblings & 10.4 \\
& One parent & 7.2 \\
& Other people / in another situation & 1.4 \\
& Alone & 14.5 \\
Academic qualification of the father & Until elementary school & 34.0 \\
& Middle school & 30.7 \\
& Secondary school & 20.9 \\
& Higher education & 8.0 \\
Academic qualification of the mother & Until elementary school & 28.2 \\
& Middle school & 36.6 \\
& Secondary school & 27.2 \\
\hline & Higher education & \\
& &
\end{tabular}


households of three or four people. Noticeably, the mothers of the students have a higher level of education than their fathers.

\section{Data Analysis}

The statistical analysis was performed using descriptive, univariate and multivariate analysis techniques.

Chi-square test of Pearson's independence was used to analyze the relation between two nominal and ordinal variables. To measure the direction and the strength of the relation between two categorical variables, the nonparametric correlation coefficient of Goodman and Kruskal's $\gamma$ was used. Mann-Whitney-Wilcoxon test was used to compare satisfaction with life between two groups. A level of significance of 0.05 was used.

A logistic regression model was adjusted to identify the factors that increase the probability of a student experiencing, on average, more than four hours per day in social media. In order to fit the model, the following strategy was pursued as recommended by Hosmer et al. (2013), after making the requested adaptation, given the number of events:

1. For the initial model, all the variables that were found to be significant in the univariate phase $(p<0.10)$ were selected.

2 . From this model, all nonsignificant variables $(p>0.05)$ were eliminated successively, and in descending order of $p$ values.

3 . It was verified if any of the variables that were not included in the initial model are shown to be significant in the presence of those in the model, in which case they were added to the model.

4 . The interactions that made sense in the context of the study were tested $(p<0.05)$.

5. A residual analysis was done by covariate patterns to search for influential observations or outliers.

The significance of variables and interactions was tested using the likelihood ratio test. When each variable was excluded, it was observed the impact it had on the estimates of the remaining coefficients. The goodness of fit was done using Hosmer's and Lemeshow's goodness-of-fit test and Cessie-van Houwelingen test. Discriminative ability of the models was evaluated by the area under the ROC curve (AUC). 
Statistical analysis was performed using software R, v. 3.4.0, free trial license (R Core Team 2017).

\section{The Senses of the Lonely Crowd, Today}

\section{Integrating the Crowd}

This section explores the ways in which young people in the sample join the online crowd. Specifically, it describes activities students enjoy doing in their free time. The focus is put on activities and time spent on social networks and broad satisfaction with life.

Results show that at least 9 out of 10 secondary school students refer that in their free time, they like to be with friends, 2 out of 3 enjoy being on social networks and almost 4 out of 10 enjoy being alone (Table 8.2).

Almost all students (97.5\%) use social networks. About half of secondary school students spend more than two hours a day in social networks (IC95\% $=[49.3 \%, 56.9 \%])$ and approximately three out of four students spend more than one hour in social networks (IC95\% $=[73.8 \%, 80.2 \%])$, and more than a quarter of young people report spending, on average, more than four hours a day in a social network (IC95\% $=[23.8 \%, 30.6 \%])$, (Fig. 8.1).

Table 8.2 Activities that students enjoy doing in their free time*

\begin{tabular}{llcc}
\hline & A lot (\%) & Little bit (\%) & Nothing (\%) \\
\hline To be with friends & 91.9 & 7.2 & 0.9 \\
To participate in social networks/spaces & 67.6 & 27.0 & 5.4 \\
Being alone & 38.8 & 46.5 & 14.8 \\
\hline
\end{tabular}

${ }^{*}$ Multiple-choice question

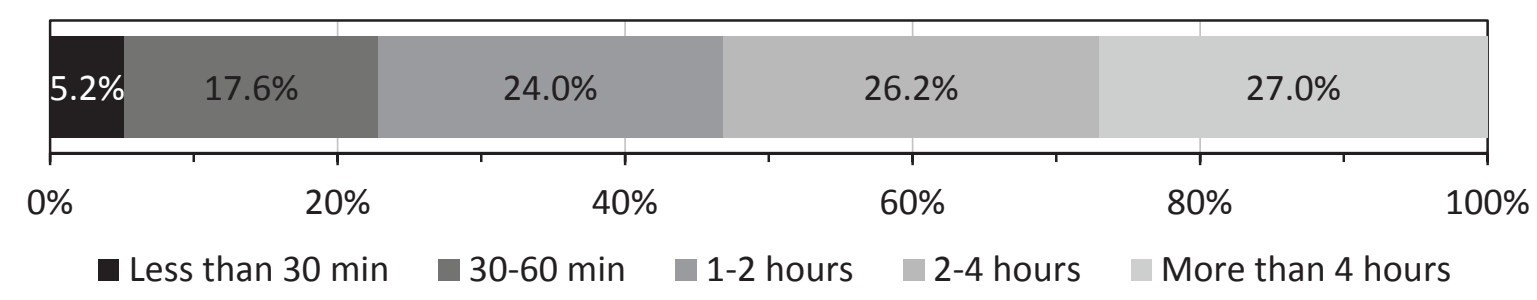

Fig. 8.1 Time (per day), on average, the students spend in social networks/spaces 
Table 8.3 Activities in virtual networks/spaces carried out by students, excluding study activities*

\begin{tabular}{llllllll}
\hline Gaming & $\begin{array}{l}\text { To } \\
\text { make/find } \\
\text { friends }\end{array}$ & $\begin{array}{l}\text { To look for } \\
\text { a job }\end{array}$ & $\begin{array}{l}\text { To spend } \\
\text { time }\end{array}$ & $\begin{array}{l}\text { To search } \\
\text { for } \\
\text { targeted } \\
\text { informa- } \\
\text { tion }\end{array}$ & $\begin{array}{l}\text { To search } \\
\text { for a } \\
\text { partner }\end{array}$ & $\begin{array}{l}\text { To relate } \\
\text { with } \\
\text { different } \\
\text { people }\end{array}$ & Other \\
\hline $47.8 \%$ & $36.5 \%$ & $5.0 \%$ & $76.1 \%$ & $26.4 \%$ & $2.7 \%$ & $27.2 \%$ & $6.8 \%$ \\
\hline
\end{tabular}

${ }^{*}$ Multiple-choice question

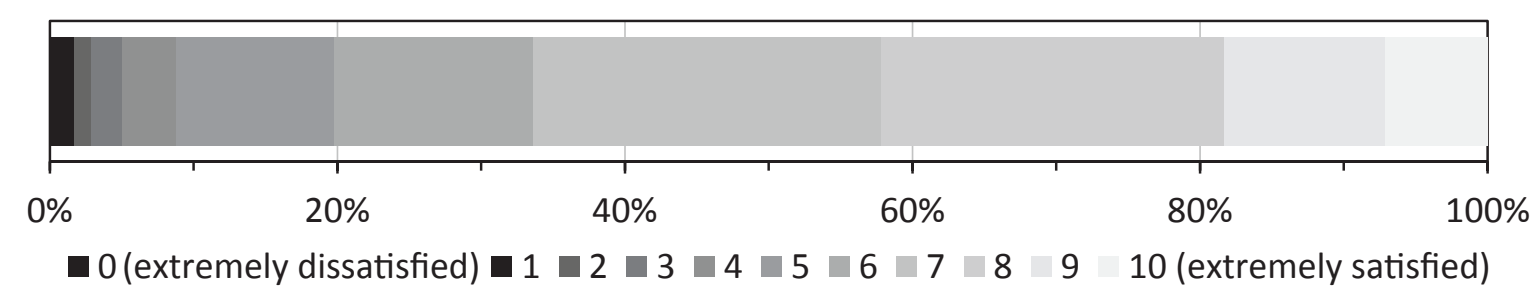

Fig. 8.2 Level of satisfaction with live in general

The overwhelming majority of students say that they participate in social networks for "spending time" (76.1\%). Other activities comprise gaming $(47.8 \%)$, to make/find friends $(36.5 \%)$, to relate with different people (27.2\%) and to search for targeted information (26.4\%) (Table 8.3).

Almost all students are satisfied or very satisfied with life (Fig. 8.2). Less than one in $10(8.8 \%)$ indicated a value less than five in the degree of satisfaction, and a little less than a half of the students (42.2\%) indicated at least eight on a scale where 10 meant maximum satisfaction. At the opposite, seven students (1.1\%) indicated that they were not satisfied, and 47 students $(7.1 \%)$ indicated that they were totally satisfied.

\section{Avoiding the Crowd?}

In addition to the previous section, which dealt with questions of joining the crowd, this section seeks to unveil some of the factors that might help to understand why some students avoid the crowd. Specifically, this section identifies and compares relations between the degrees of satisfaction among students who refer that in their free time they prefer being with friends, to participate in social networks/spaces or being alone. Moreover, it explores 
correlations between the degree of satisfaction with life and variables that illustrate the activities with which students like to occupy their free time.

Results show that there is a significant difference in the degree of satisfaction with life among the students who refer that in their free time, they like very much being alone, and those who refer that do not like, or like a bit to be alone in their free time (median "very" $=6.3$; median "little or nothing" $=7.3, p<0.001)$. Students who like very much being alone are the less satisfied with life.

There is no significant difference in the degree of satisfaction with life among the students who like very much and those who like little or nothing to participate in social networks in their free time (median "very" $=7.0$; median "little or nothing" $=6.8, p=0.300$ ).

There is no significant correlation between the degree of satisfaction with life and almost all variables that represent the activities with which students like to occupy their free time. Only the increase in the degree of satisfaction with life leads to an increase in the willing to occupy free time playing on the computer or tablet $(\gamma=-0.34)$. Also, the increase in the degree of satisfaction leads to an increase in the willing to occupy their free time reading $(\gamma=0.25)$ or being with friends $(\gamma=0.60)$.

The greater the average time spent in social networks, the greater the pleasure of occupying their free time playing console $(\gamma=0.35)$ and playing games on the computer or tablet $(\gamma=0.28)$. The opposite behavior was observed in the will of students in spending time with their family $(\gamma=-$ $0.43)$ and walking $(\gamma=-0.28)$.

The more the students enjoy spending their free time in social networks, the more the students enjoy being with friends $(\gamma=0.71)$, navigating the Internet $(\gamma=0.59)$, shopping $(\gamma=0.43)$, walking $(\gamma=0.42)$, listening to music $(\gamma=0.31)$ and making cultural programs with family or friends $(\gamma=0.28)$.

Among those students who like very much to spend their free time in social networks, no association was found between what they do on social networks, and how much they like to spend their free time with friends ( $p$ $=0.300$ ) (Table 8.4). However, it was found an association between what they do on the social networks and liking a lot/little or nothing of being alone $(p=0.008)$ (Table 8.4). Among students who say they like little or nothing being alone in their free time, based on the inexistence relation, there are more students mentioning that they use the social networks to play, and fewer students mentioning the use of social networks to look for targeted information. 
Table 8.4 Activities carried out by students in virtual networks / spaces (excluding study activities) for students who in their free time like a lot being with friends or alone*

\begin{tabular}{|c|c|c|c|c|c|}
\hline \multirow[b]{2}{*}{$\begin{array}{l}\text { Students who } \\
\text { in their free } \\
\text { time like a lot } \\
\text { being }\end{array}$} & \multicolumn{5}{|c|}{ Activities carried out in virtual networks/spaces } \\
\hline & $\begin{array}{l}\text { Gaming } \\
(\%)\end{array}$ & $\begin{array}{l}\text { To make/find } \\
\text { friends }(\%)\end{array}$ & $\begin{array}{l}\text { To spend time } \\
(\%)\end{array}$ & $\begin{array}{l}\text { To search for } \\
\text { targeted } \\
\text { information } \\
(\%)\end{array}$ & $\begin{array}{l}\text { To relate with } \\
\text { different } \\
\text { people (\%) }\end{array}$ \\
\hline With friends & 95.3 & 97.8 & 96.9 & 93.3 & 96.4 \\
\hline Alone & 28.8 & 32.6 & 37.4 & 47.1 & 40.9 \\
\hline
\end{tabular}

*Multiple-choice question

\section{Engaging the Crowd}

Differently from the first section, this one seeks more than the reasons to simply join the crowd. Making use of univariate logistic models, where the event of interest is the student spending, on average, more than four hours per day in social networks, this section explores what can be a signal of engaging the crowd, namely the factors that significantly increase the probability of a student spending more than four hours a day on social networks.

Results show that there is no association between how much students like to spend their free time in social networks or being alone and belonging to some association/organization/club $\left(\chi_{(2)}^{2}=0.79, p=0.674\right.$ and $\chi_{(2)}^{2}$ $=4.10, p=0.129$, respectively). In other words, what makes students to belong or to participate somehow in an association is not related to how much they like spending their free time in social networks or being alone.

No association was found between how much students like spending their free time in social networks and their interest in politics $\left(\chi_{(6)}^{2}=6.62\right.$, $p=0.357)$. However, it was found a significant association between how much students like to spend their free time being alone and their interest in politics $\left(\chi_{(6)}^{2}=18.40, p=0.005\right)$. Based on the inexistence of relation, there are more students mentioning that they are very interested in politics and really like to be alone in their free time, and also that they have a little interest in politics and like little to be alone; and fewer students mentioning to have a little interest in politics and really like to be alone in their free 
time, as well as fewer students referring that they have much interest in politics and like little to be alone in their free time.

No significant association was found between how much students like to spend their free time in social networks or being alone, and the following behaviors adopted in the last twelve months (all values $p>0.114$ ): to contact with a politician, or with a member of the central or local government; to work for a political party or civic movement; to work in an organization or association of another type; volunteering; to wear a campaign/movement sticker; to sign a petition; to participate in a manifestation; or to boycott certain products.

According to univariate logistic models, where the event of interest is the student spending, on average, more than four hours per day in social networks, the factors that significantly increase the probability of a student being more than four hours a day on social networks are: to be a female $(p=$ $0.050)$; the father has higher education $(p=0009)$; the mother has higher education $(p=0.021)$; to self-assess his/her performance as a student as sufficient or inferior $(p=0.031)$; to be more religious $(p=0.039)$; regarding the leisure activities, liking very much to read $(p=0.003)$, he/she loves to listen to music $(p=0.022)$, likes to watch TV $(p=0.052)$, enjoys very much shopping $(p<0.001)$; does not like very much to engage in cultural programs with the family $(p=0.015)$; do not like to practice physical activity $(p=0.033)$; likes very much to play on the mobile phone $(p<0.001)$; do not like to play board games $(p=0.041)$; likes very much to spend time on the Internet $(p<0.001)$; has little or no interest in politics $(p=0.008)$; for the next 10-15 years wishes little or nothing to have an independent life $(p=0.006)$, and wishes very much to buy a car $(p=0.050)$.

The adjusted multivariate logistic model (Table 8.5) fits well the data (Hosmer and Lemeshow goodness-of-fit test: $p=0.934$; Cessie Van Howelingen goodness-of-fit test: $p=0.656$ ), and it has a good discriminative capacity (AUC of the ROC curve $=0.732$ ). Based on the odds ratio, the following conclusions can be drawn:

1. A student who does not like very much to read in leisure times is 2 times more likely to stay more than four hours a day in social networks than a student who likes very much to read.

2. A student who does not like very much to do cultural programs with the family in leisure times is 1.6 times more likely to stay more than four hours a day in social networks than a student who likes very much to do cultural programs with the family. 


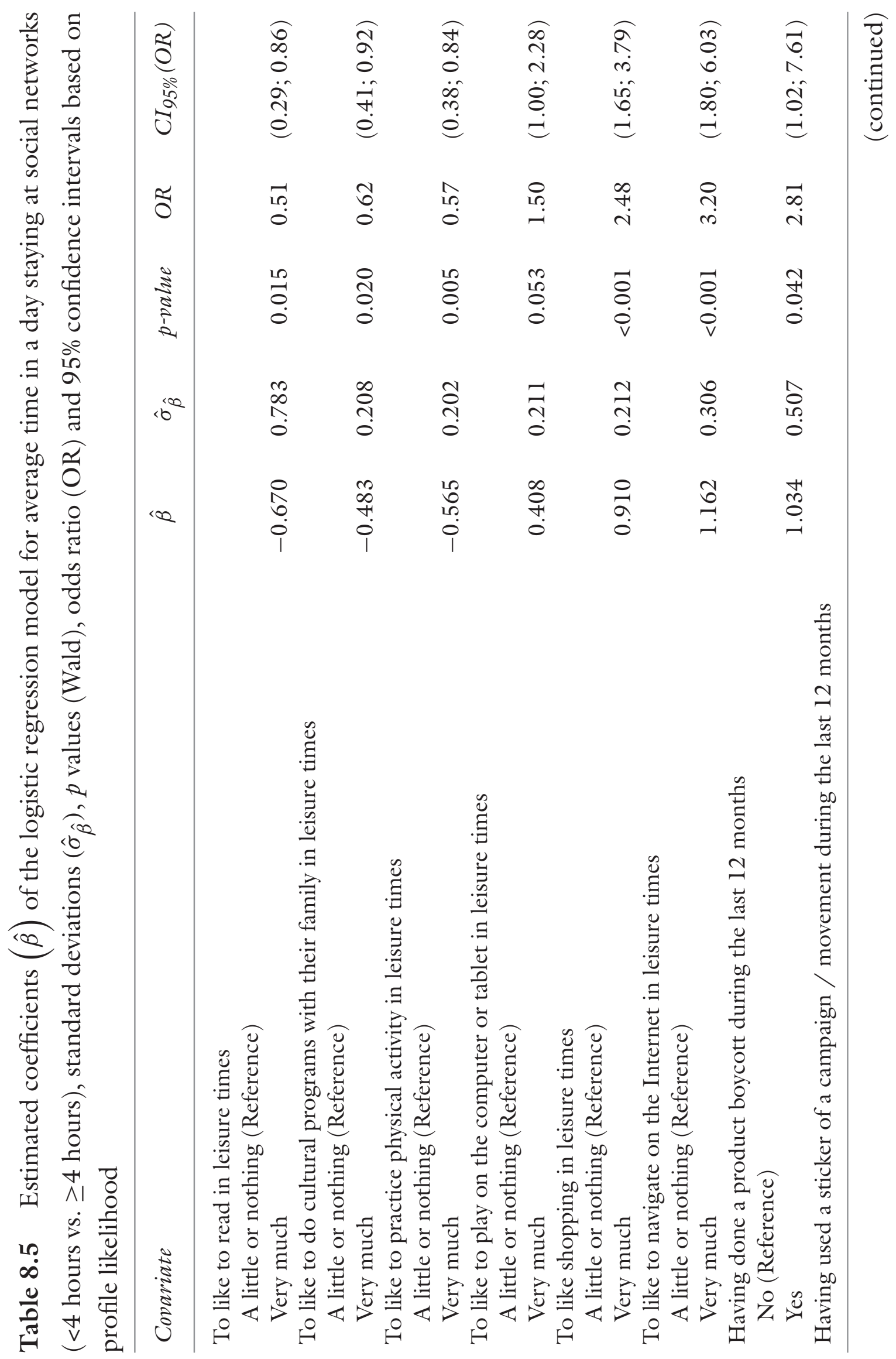


R. P. COSTA ET AL.

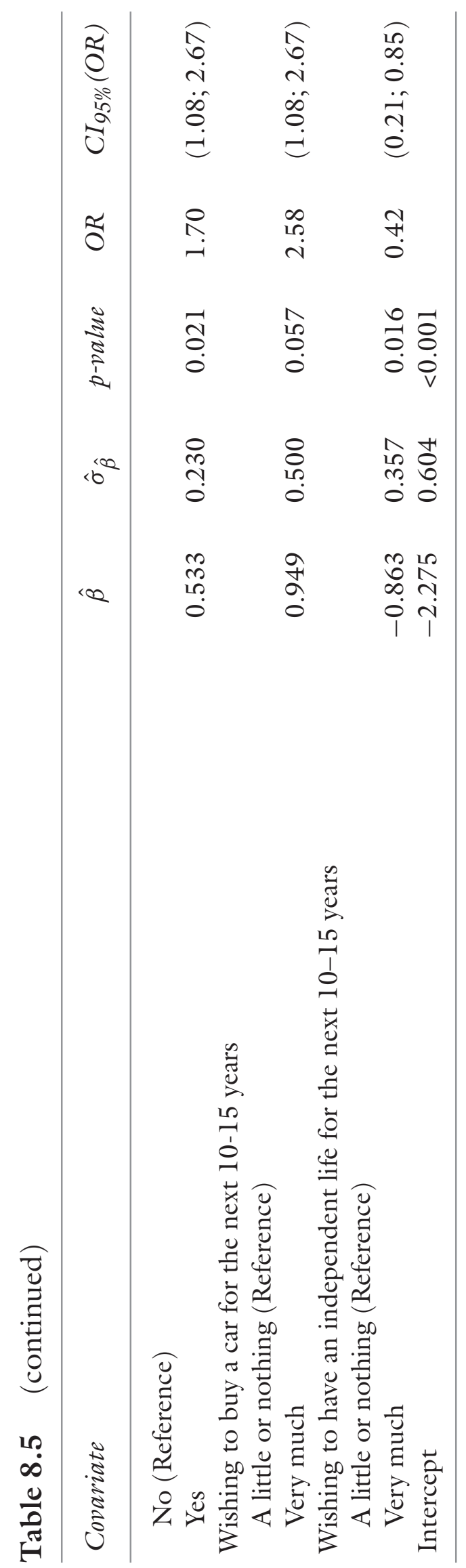


3. A student who does not like very much to practice physical activity in leisure times is 1.8 times more likely to stay more than four hours a day in social networks than a student who likes very much practicing physical activity.

4. A student who loves to play on the computer or tablet in leisure times is $\mathbf{1 . 5}$ times more likely to stay more than four hours a day in social networks than a student who doesn't like very much to play on the computer or tablet.

5. A student who enjoys shopping very much in leisure times is 2.5 times more likely to stay more than four hours a day in social networks than a student who doesn't like shopping.

6. A student who likes very much being on the Internet in leisure times is 3.2 times more likely to stay more than four hours a day in social networks than a student who doesn't like being on the Internet.

7. A student who wore a campaign/movement sticker in the last 12 months is 1.7 times more likely to stay more than four hours a day in social networks than a student who did not adopt this behavior.

8. A student who has boycotted certain products in the last 12 months is 2.8 times more likely to stay more than four hours a day in social networks than a student who did not adopt this behavior.

9. A student who wishes only a little or nothing to have an independent life for the next 10-15 years is 2.4 times more likely to stay more than four hours a day in social networks than a student who wishes this very much.

10. A student who wishes very much to buy a car for the next $10-15$ years is 2.6 times more likely to stay more than four hours a day in social networks than a student who wishes this a little or nothing.

According to this model, the profile that maximizes the probability of a student staying more than four hours a day in social networks is a student who likes very much to occupy his/her leisure time shopping, playing on the computer or tablet, and navigating on the Internet, and who in the leisure time does not like very much to spend time reading, to do cultural programs with the family, and to practice physical activity; who wore a campaign/movement sticker and has boycotted certain products in the last 12 months, who wishes very much to buy a car, and does not wish to have an independent life for the next 10-15 years. 


\section{CONCluding Remarks}

This text made use of David Riesman's classic The Lonely Crowd to discuss its power in reading contemporary society, particularly youth. Additionally inspired by the work of Carsten Stage (2013), when referring to the "online crowd", it provides an empirical basis for documenting youth, emotions and loneliness among a representative sample of students of secondary schools in Évora, Portugal.

First and immediate conclusions arising when analyzing these data can be aggregated in the idea of "joining the crowd", as something inevitable and pervasive among students. When questioned about how they spend their free time, young people in the sample clearly declare they join the online crowd. Results show that almost all students use social networks, and more than a quarter of young people report spending, on average, more than four hours a day in a social network. The overwhelming majority of students attend these spaces for "spending time", and almost all students are satisfied or very satisfied with their lives.

A set of partial results can be joined together under the title of "avoiding the crowd". Regarding this specific topic, it is worth saying that data show that there is a significant difference in the degree of satisfaction with life among the students who refer that in their free time, they like very much being alone, and those who refer that do not like, or like a bit to be alone in their free time. Additionally, students who like very much being alone are the less satisfied with life. Among those students who like very much to spend their free time in social networks, it was found an association between what they do on the social networks and liking a lot/little or nothing of being alone.

Finally, data also point to the degree in which some students engage the crowd. This is different from simply joining it, as it means a deeper sense of belonging and interacting with the online crowd. When analyzing the results, a significant association was found between how much students like to spend their free time being alone and their interest in politics. According to the adjusted multivariate logistic model, the profile that maximizes the probability of a student staying more than four hours a day in social networks highlights the student who tends to be sedentary, or at least somehow accommodated, given that in his/her free time, he/she likes very much to play on the PC/tablet and surfing on the Internet, and do not like to practice physical activity and do not want to be independent. 
They are also students who do not like to read, nor to do cultural programs with the family. At the same time, those students are active in the sense they've boycotted certain products recently, so they cannot be considered as completely aside and disinterested in the world around. At last, it seems those students do not want to be independent in the next 10-15 years, turning the experience of living in their parents' house until age 30 as something "normal". As this study does not advance for direct explanations of why this happens, researchers agree that more research is needed to understand better the young people's choices and paths.

As a result of the foregoing, three main remarks should be highlighted. The first has to do with the importance, usefulness and timeliness of the influential image of "the lonely crowd", as coined by David Riesman and its collaborators in the 50s. Second, and directly related to this, the interest of using the concept of "online crowd" (Stage 2013) as a metaphor that expands the "lonely crowd" and allows to understand the specificity of a networked and digital generation such as the current one. Third, the plurality that should be emphasized when reading such an online crowd, as different modes of relating to it arise. In fact, as demonstrated by this study, while some of the young people join it, others avoid or engage in it.

Despite being a small-scale and geographically circumscribe study, this work is insightful when looking at the multiple and multiplex relationships and meanings between media and experiences of loneliness. As it broadly follows previous literature on the topic, specifically regarding children, youth and the Internet and social media's accesses, uses, risks and mediations (Haddon 2015), also in Portugal (Ponte et al. 2012), it is inspiring for how much more there is to investigate. As the crowd becomes more numerous and dense, and as new generations of young people replace older ones, so too it will certainly continue to motivate further study and research.

Acknowledgements Rosalina Costa is affiliated researcher at CICS.NOVA.UÉvora-The Interdisciplinary Centre of Social Sciences, a research center funded by FCT, the Portuguese Foundation for Science and Technology (project UID/SOC/04647/2019 (CICS.NOVA)). Paulo Infante, Anabela Afonso and Gonçalo Jacinto are members of CIMA-Research Center in Mathematics and Applications, also funded by FCT (project UID/MAT/04674/2019 (CIMA)). The authors gratefully acknowledge the support along all phases of the study development provided by the University of Evora, the research centers CICS.NOVA.UÉvora and CIMA, and the Évora City Council. The authors are 
also grateful for the kind assistance and fruitful collaboration gained through the close work with José Conde and Maria Luísa Policarpo, senior technicians of the Division of Youth and Sports of the Évora City Council, who were vital for accomplishing the work within the deadlines and objectives originally outlined.

\section{Notes}

1. September 27, 1954 | Vol. LXIV No. 13, with the title "Social Scientist David Riesman. What is the American character?". Cover Credit: Ernest Hamlin Baker. The cover content can be found online at http://content.time.com/ time/covers/0,16641,19540927,00.html. Accessed March 29, 2019.

2. According to Herbert J. Gans (1997), The Lonely Crowd had already sold one million copies by 1971. The author adds that by the end of 1995, Nathan Glazer reported (personal communication) that the book had sold 1,434,000 copies. The runner-up to The Lonely Crowd was Elliot Liebow's Tally's Corner (1967), which had sold 701,000 copies through 1995.

3. Riesman's attempt to link his theory of character with demographic shifts was an aspect of the book that was widely criticized in the years that followed The Lonely Crowd publication, and that Riesman dissociated himself from later (McLaughlin 2001).

4. With the United States' entry into World War II, Riesman joined the Sperry Gyroscope Company, where he was first assistant to the treasurer and then war contract termination manager (McClay 1998). This may help to explain the use of this metaphor to describe what orients the inner-directed character, keeping it on a deep-steady course in life.

5. The International Sociological Association Congress Programme Committee carried on in 1997 an opinion survey in order to identify ten most influential books for sociologists. ISA members were asked to list five books published in the twentieth century which were most influential in their work as sociologists. $16 \%$ of ISA members ( 455 out of 2785 ) participated in the survey. The final list is available online through ISA webpage, at https://www.isa-sociology. org/en/about-isa/history-of-isa/books-of-the-xx-century. Accessed March 29, 2019, and The Lonely Crowd does not appear in the ten most influential books.

6. The expression "the online crowd" belongs to Carsten Stage (2013) in a specific article where the author investigates, from a psychological perspective, the concept of the "crowd", as developed by Gustave Le Bon, in understanding the new types of affectively charged collectivities created via spontaneous interaction on various social media platforms.

7. In order to develop such a study, the Municipality of Évora requested the scientific collaboration of the University of Évora. The research team composed by the authors worked closely with the senior technicians of the Division of 
Youth and Sports of the Évora City Council (DJD, Divisão de Juventude e Desporto). More information about the Youth Plan for the Municipality of Évora is available online through the Municipality of Évora's webpage, at http://www.cm-evora.pt/pt/site-viver/desportoejuventude/PMJ.

\section{REFERENCES}

Barthel-Bouchier, D. 2019. The Lonely Crowd. International Encyclopedia of the Social Sciences. Encyclopedia.com. https://www.encyclopedia.com. Accessed March 29, 2019.

Boyd, D. 2014. It's Complicated: The Social Lives of Networked Teens. New Haven and London: Yale University Press.

Costa, R.M., I. Patrão, and M. Machado. 2018. Problematic Internet Use and Feelings of Loneliness. International Journal of Psychiatry in Clinical Practice. Published Online: December 20, 2018. https://doi.org/10.1080/13651501. 2018.1539180. Accessed March 18, 2019.

Gans, H., N. Glazer, J. Gusfield, and C. Jencks, eds. 1979. On the Making of American: Essays in Honor of David Riesman. Philadelphia: University of Pennsylvania Press.

Gans, H. 1997. Best-Sellers by Sociologists: An Exploratory Study. Contemporary Sociology 26 (2): 131-135. https://www.jstor.org/stable/2076741.

Haddon, L. 2015. Social Media and Youth. In The International Encyclopedia of Digital Communication and Society, ed. Robin Mansell and Peng Hwa Ang, 1-9. Chichester, UK: Wiley-Blackwell. https://doi.org/10.1002/ 9781118290743.wbiedcs088.

Heberle, R. 1956. A Note on Riesman's The Lonely Crowd. American Journal of Sociology 62 (1): 34-36. https://www.jstor.org/stable/2773802.

Hosmer, D., S. Lemeshow, and R. Sturdivant. 2013. Applied Logistic Regression, 3rd ed. New York: Wiley.

Infante, P., R.P. Costa, A. Afonso, G. Jacinto, J. Conde, and M.L. Policarpo. 2018. Diagnóstico Juvenil: os Alunos do Ensino Secundário. Évora: Câmara Municipal de Évora e Centro de Investigação em Matemática e Aplicações da Universidade de Évora.

Lipset, S.M., and L. Lowenthal (eds.). 1961. Culture and Social Character: The Work of David Riesman Reviewed. Glencoe: The Fress Press.

Livingstone, S., and L. Haddon (eds.). 2009. Kids Online: Opportunities and Risks for Children. Bristol, UK: Policy Press.

Mascheroni, G., and K. Olafsson. 2014. Net Children Go Mobile: Risks and Opportunities, 2nd ed. Milano: Educatt.

Mascheroni, G., C. Ponte, and A. Jorge. 2018. Digital Parenting. Göteborg: Nordicom. 
McClay, W. 1998. The Lonely Crowd After Fifty Years. The Wilson Quarterly, Summer, 35-43.

McLaughlin, N. 2001. Critical Theory Meets America: Riesman, Fromm, and The Lonely Crowd. The American Sociologist 32 (1): 5-26. https://doi.org/10. 1007/s12108-001-1009-4.

Mullan, K., and S. Chatzitheochari. 2019. Changing Times Together? A TimeDiary Analysis of Family Time in the Digital Age in the United Kingdom. First Published: March 11, 2019. https://doi.org/10.1111/jomf.12564. Accessed March 20, 2019.

Ponte, C., A. Jorge, J.A. Simões, and D.S. Cardoso. Org. 2012. Crianças e internet em Portugal, acessos, usos, riscos, mediações: resultados do inquérito europeu EU KIDS ONLINE. Coimbra: Minerva.

R Core Team. 2017. R: A Language and Environment for Statistical Computing. Vienna: R Foundation for Statistical Computing. https://www.R-project.org/.

Riesman, D., N. Glazer, and R. Denny. 1950. The Lonely Crowd: A Study of the Changing American Character. New Haven: Yale University Press.

Riesman, D., N. Glazer, and R. Denny. 1989 [1950]. The Lonely Crowd: A Study of the Changing American Character. Abridged ed. with 1961 and 1969 prefaces. New Haven and London: Yale University Press.

Riesman, D. 1998. The Innocence of The Lonely Crowd. Society 35 (2): 339-342. https://doi.org/10.1007/BF02838159.

Stage, C. 2013. The Online Crowd: A Contradiction in Terms? On the Potentials of Gustave Le Bon's Crowd Psychology in an Analysis of Affective Blogging. Distinktion: Journal of Social Theory 14 (2): 211-226. https://doi.org/10.1080/ 1600910X.2013.773261.

Thompson, R., L. Berriman, and S. Bragg. 2018. Researching Everyday Childhoods: Time, Technology and Documentation in a Digital Age. London: Bloomsbury.

Twenge, J.M. 2017. iGen. New York: Atria Books.

Wrong, D. 1992. Review: “The Lonely Crowd” Revisited. Sociological Forum 7 (2): 381-389. https://www.jstor.org/stable/684319. 